\title{
Written with seed: the political ecology of memory in Madagascar
}

\author{
Sarah Osterhoudt ${ }^{1}$ \\ Indiana University, USA
}

\begin{abstract}
In this article, I bring together work in political ecology and environmental anthropology to examine how smallholder farmers in Madagascar articulate and embody political and economic histories through the everyday interactions with the commodities cultivated in their fields and forests. I ask: how does the work of cultivating land connect with the art of cultivating memory? In considering this question, I draw from ethnographic research in the agrarian village of Imorona, located in Northeastern Madagascar. In Imorona, smallholder farmers turn towards the materials in their agroforestry fields to reference the more painful political epics of their collective pasts - memories that otherwise remain largely silent within everyday realms of Malagasy culture. I show how the stories people tell of their shifting relationships to commodities including rosewood, vanilla and cloves bring together political and economic 'histories writ large' with more personal and intimate 'histories writ small.' Overall, I argue that the analytical approach of a 'political ecology of memory' offers the productive capacity to look both outward towards others, and inwards towards self. In the process, it elucidates the ways that people render global histories personal.
\end{abstract}

Key words: Political ecology; memory; agroforestry; commodities; Madagascar; Indian Ocean.

\section{Résumé}

Dans cet article, je rassemble le travail de l'écologie politique et l'anthropologie environnementale pour examiner la façon dont les petits exploitants agricoles à Madagascar articuler et incarner des histoires politiques et économiques à travers les interactions quotidiennes avec les produits cultivés dans les champs et les forêts. Je demande: comment le travail de cultiver la terre se connecter avec l'art de cultiver la mémoire? En examinant cette question, je me sers de mes recherches ethnographiques dans le village agraire de Imorona, situé dans le nord de Madagascar. En Imorona, les petits exploitants se tournent vers les matériaux dans leurs domaines de l'agroforesterie pour référencer les épopées politiques plus douloureux de leur passé collectif - souvenirs qui restent par ailleurs largement silencieux dans les domaines du quotidien de la culture malgache. Je montre comment les histoires que les gens racontent leurs relations changeantes à des produits, y compris le bois de rose, de vanille et de girofle réunir un histoire politique et économique «au sens large» avec des histoires plus personnelle et intime, «bref et petit». Dans l'ensemble, je soutiens que l'approche analytique d'une «écologie politique de la mémoire» offre la capacité de regarder à la fois vers l'extérieur les autres, et vers l'intérieur vers l'auto. Dans le processus, il élucide les façons que les gens rendent des histoires mondiales personnelles.

Mots clés: écologie politique; Mémoire; agroforesterie; produits de base; Madagascar; océan Indien

\section{Resumen}

En este artículo, utilizo la ecología política y la antropología ambiental para examinar cómo los pequeños productores en Madagascar articulado y encarno historias políticas y económicas, a través de las interacciones

\footnotetext{
${ }^{1}$ Dr. Sarah Osterhoudt, Assistant Professor of Anthropology, Indiana University, Bloomington, IN, USA. Email: srosterh "at" indiana.edu. I thank the farmers in the communities of Imorona, Madagascar for their invaluable assistance with this research, conducted between 2005-2007 and 2011-2012. I am also grateful for the constructive feedback and suggestions on earlier versions, including comments from Michael Dove, Kalyanakrishnan Sivaramakrishnan, Alison Richard, Michael McGovern, Beth Buggenhagen, Gracia Clark, Maria Grosz-Ngate, and from anonymous reviewers. I had the opportunity to present this work at the African Studies Colloquium at Indiana University and greatly benefited from the comments of the attendees. Funding support was generously provided by the Wenner-Gren Foundation, the FulbrightHays Doctoral Dissertation Research Abroad Program, and the Lewis B. Cullman Foundation. At Yale University, this research was supported by the MacMillan Center for International Research, the Program in Agrarian Studies, the Lindsay Center for African Research, and the Tropical Resources Institute.
} 
cotidianas con los productos que se cultivan en sus campos y bosques. Me pregunto: ¿Cómo funciona el cultivo de la tierra de conectarse con el arte de cultivar la memoria? Al considerar esta cuestión, yo uso la investigación etnográfica en el pueblo de Imorona, situada en el noreste de Madagascar. En Imorona, los pequeños agricultores utilizan materiales en sus campos agroforestales, para recordar episodios dolorosos en el pasado - los recuerdos que de otro modo permanecen en silencio dentro de la cultura malgache hoy. Muestro cómo las historias que la gente cuenta acerca de su cambio de relaciones con los productos básicos incluyendo palo de rosa, vainilla y clavo de olor - reunir a grandes historias políticas y económicas con las historias más personales e íntimas. En general, se argumenta que el enfoque analítico de una "ecología política de la memoria" puede mirar hacia el exterior hacia los demás y hacia adentro hacia el auto. En el proceso, hace que clarifica las formas en que la gente hace las historias globales, las personales.

Palabras clave: ecología política; memoria; agroforestal; productos básicos; Madagascar; Océano Indio.

\section{Introduction: landscapes of remembering and forgetting}

In the agrarian village of Imorona, in the Mananara Nord region of Northeastern Madagascar, history hovers closely over everyday life. First, as with many places in Madagascar, the ancestors of Imorona play an active role in the social life of the community, and the living pay close attention to what the dead may think of their actions (Bloch 1985; Cole 2001; Lambek 2002). Many local families can trace the ownership of their agricultural fields back multiple generations, and walking through these landscapes it is common for people to remark upon the great-grandmother who planted a particular litchi tree, or the grandfather who first harvested cloves on the property. The community is home to several historians, who are known for their knowledge of the early political and social history of the region. Memory is also preserved and passed down through those individuals skilled at the art of tantara story telling --- stories that address a range of subjects including the battles between early farmers and wild pigs, the courtship customs of times gone by, and the lineages of ancestral burial grounds (Osterhoudt forthcoming). Overall, as Maurice Bloch aptly summarized, Madagascar is a place where the past is fundamentally brought to bear on the present (Bloch 1977, 1998; see also Kottak 1980).

Yet, for all its richness, there are also apparent gaps in the oral history record of the Imorona region. Both the historians and storytellers I spoke with, for example, remained largely quiet on the more painful subjects of the region's political past, including times of forced labor, colonialism, and war. When I brought up such topics directly, the conversation would inevitably falter, as people muttered a few words and then abruptly changed the subject. ${ }^{2}$ In such moments, I did not push people to talk, but followed their lead in turning towards other matters. Mostly, I continued with my main ethnographic work, accompanying smallholder farmers as they went about their everyday agrarian tasks and noting the ways cultivated landscapes became sites of cultural meaning.

Once I began working with farmers in their fields, people began to discuss with me the very subjects they previously avoided in our conversations in town: subjects including the violent histories of forced labor, colonialism, and war. For example, one day while helping a friend gather honey in his vanilla garden, he pointed out some tobacco leaves growing in the corner of his field. I remarked that I hadn't seen many fields in Imorona with tobacco growing in them. He told me that during the time of colonialism, almost everyone grew a little tobacco in his or her fields. Not seeing the connection between the two - tobacco and French colonialism - I asked him to explain:

\footnotetext{
${ }^{2}$ Other scholars working in Madagascar have made similar observations. The historian Pier Larson writes that when speaking with people in Madagascar about slavery, "...conversations were often surreptitious and hushed. Many of my hosts... rose to close windows and doors and required me to stop my recording device before agreeing to speak (2000:32)." Similarly, anthropologist Jennifer Cole writes that the members of the Southern Betsimisaraka village of Ambodiharina seemed to have forgotten the "deeply disruptive" experiences of French colonialism (2001:12). She asks, "how is it possible that the Betsimisaraka live among the visible remnants of the colonial past, yet that past appears to be absent in every significant way from the intimate round of their daily lives (p.102)?"
} 
Before, people all grew some tobacco, because the French only allowed them to take a rest if they asked to smoke a cigarette. Back then, everyone smoked! Sometimes they were so tired but had no tobacco left so they just rolled up banana leaves they found in their fields and smoked them, just so they could sit for a moment. Back then, people had to work very hard.

In this article, I ask: How does the work of cultivating land connect with the art of cultivating memory? In particular, I examine the ways people filter the painful political epic stories of the past through the everyday ecologies of their local landscapes. I argue that by talking about the past by referencing the materials in their fields people remove themselves from the historical spotlight, elevating instead the landscape as the protagonist of history. This rhetorical move, in turn, allows the speaker to follow the Malagasy preference for speaking indirectly and through metaphor, especially when addressing difficult or controversial subjects (Cole 2001; Graeber 2007; Huff 2014). Overall, by talking through landscapes, painful epics of history are allowed emerge "out of the corner of one's eye" (Jackson 1984).

Highlighting the connections between cultivating agricultural commodities and cultivating political memories brings together work in political ecology and environmental anthropology. It incorporates the fundamental themes of political ecology literature, focusing on the linkages between history, power, production, trade, and natural resources (Biersack 2006; Bryant 1998; Peet et al. 2011; Wolf 1982). At the same time, it employs the lens of ethnography up close, noting the recursive relationships between memory, meaning, personhood and local landscapes (Basso 1996; Dove 1999; Giles-Vernick 2001; Nazarea 2006; Turner 1967). As such, this discussion brings together approaches to documenting 'history writ large' with those that examine 'history writ small.' Navigating local landscapes with farmers on a tree-by-tree basis reveals how global trade systems become grounded - literally and figuratively - in everyday meanings, memories, and practice (Meitzner Yoder 2011; Tsing 2015). ${ }^{3}$ In short, a political ecology of memory framework examines how people render global histories personal.

I first present a brief overview of the Imorona and Mananara Nord region. I then present ethnographic examples showing the connections between the commodities of rosewood, vanilla and cloves and memories of political eras including forced labor, colonialism and war. I note how landscapes do not only reflect these harder moments of history, but also serve as a reminder of inspiring times of resiliency and triumph. I argue that such memories are not static, but that in turning to their fields farmers actively interface with the historical record, remembering and re-articulating the past in a way that simultaneously provides resources for the present. Finally, I expand upon the concept of a 'political ecology of memory' and what it may contribute to on-going conversations on the dynamic interactions between political power, environmental meanings, and the everyday constructions of personhood.

\section{Overview of Imorona and the Mananara Nord region}

The agrarian village of Imorona is situated on the Bay of Antongil in the Mananara Nord (Mananara Avaratra) region of Northeastern Madagascar (Figure 1). At first glance, Imorona seems to exemplify an isolated African outpost - an island within an island, situated 'back in time.' Here, farmers prepare their rice fields using simple shovels and harvest crops by hand. The majority of villages surrounding Mananara, including Imorona, do not have access to electricity or running water. Roads connecting Mananara with other parts of Madagascar are in notoriously bad repair and getting to and from the region by land is at best challenging and at worst dangerous. Boat travel, especially during cyclone season, is precarious.

Although seemingly removed from the world at large, this region has long been imbricated in the global trade networks of the Indian Ocean. The Portuguese and the Dutch established trading posts around Mananara Nord during the sixteenth and seventeenth centuries, trading goods such as cloth in return for forest products including honey, timber, and gold (Campbell 2005; Olson 1984; Randrianja and Ellis 2009). The

\footnotetext{
${ }^{3}$ Meitzner Yoder's discussion of sandalwood and beeswax as "constellations" connecting realms of ecology, history, and politics parallels the ways certain commodities in Madagascar connect with larger colonial histories of production and trade (2011).
} 
Antongil Bay also served as an important global pirate hub in the late eighteenth and early nineteenth century (Ellis 2007). Over the nineteenth and early twentieth centuries, French colonial traders, as well as merchants from India and China, purchased commodities from the area including sugar cane, black pepper, wild latex, coffee, and cacao (Osterhoudt forthcoming). Today, Imorona farmers produce the export crops of cloves and vanilla in significant volume. ${ }^{4}$

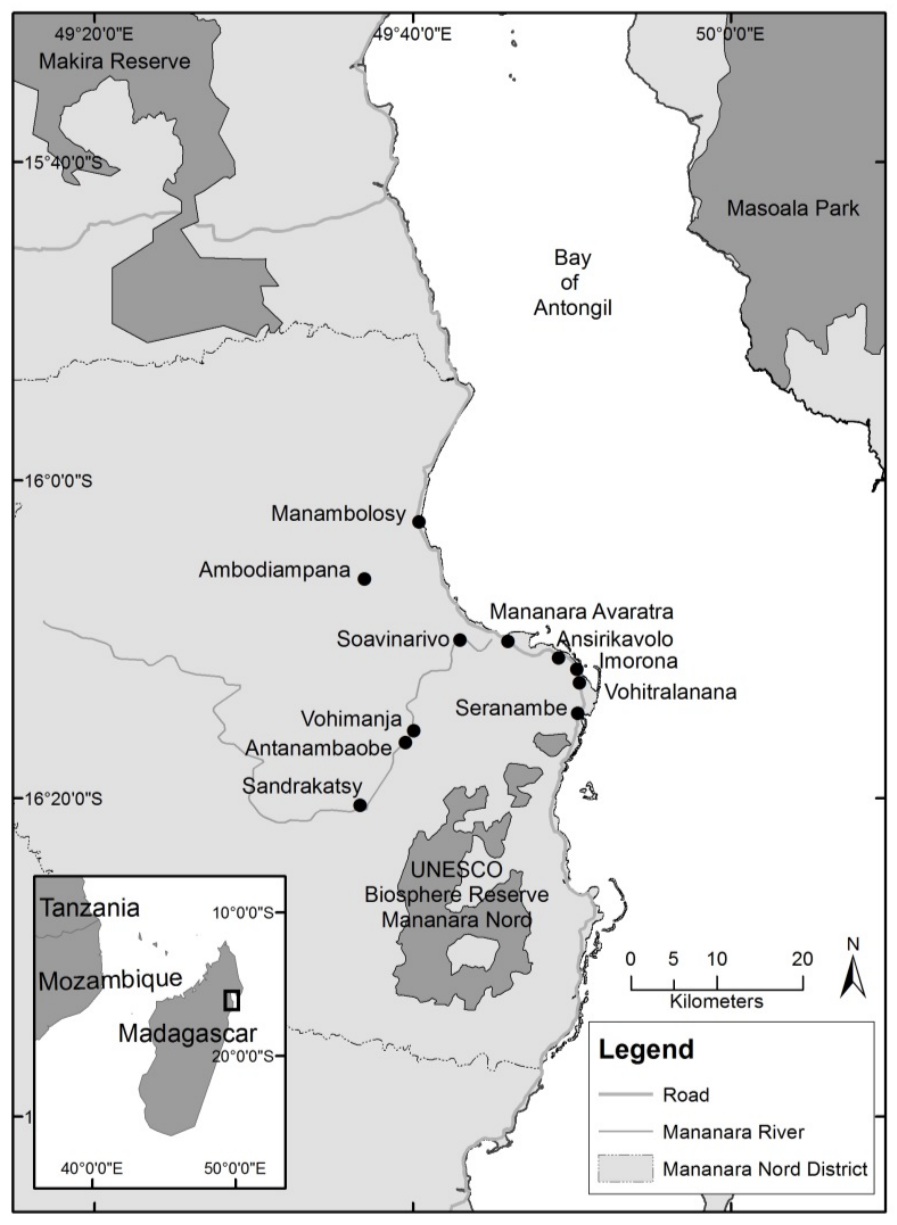

Figure 1: Map of the Mananara Avaratra region of Northeastern Madagascar. Source: Osterhoudt forthcoming.

While bringing opportunity for economic advancement, such consistent contact with powerful outside entities has also brought the threat of the appropriation of natural resources, especially of agricultural land. Throughout the past centuries, for example, Mananara smallholder farmers have faced outside traders offering up what seemed like exorbitant sums to buy large swaths of land (Campbell 1981, 2012), French colonial officials pressuring farmers to adopt monoculture cash-crop agricultural systems (Larson 2000; Middleton 1999), and notoriously volatile commodity markets (Odoux 2003; Walsh 2005). Furthermore, this political and economic uncertainty has occurred in conjunction with frequent and violent cyclones (Donque 1972).

\footnotetext{
${ }^{4}$ Farmers of the region also produce coffee as a cash crop, though this commodity primarily serves the domestic Malagasy
} market. 
Yet, despite these compounded risks and disturbances, individuals in the Mananara region have largely avoided the more serious pitfalls to befall smallholder farmers in other places who were similarly incorporated into volatile cash crop markets ( $\mathrm{Li} \mathrm{2014;} \mathrm{Tsing} \mathrm{2005).} \mathrm{Most} \mathrm{importantly,} \mathrm{families} \mathrm{in} \mathrm{the}$ Mananara region have in general maintained ownership of their agricultural land. ${ }^{5}$ In addition, farmers have continued to cultivate subsistence crops alongside market crops, providing a degree of food security in times of market downturns. They have also historically eschewed strategies of planting fields with only one type of commodity crop, opting instead to keep their hillside land in diversified agroforestry systems. ${ }^{6}$

In part due to the long relationship between family lineages and agricultural land, the cultivated landscapes of Mananara do not only contain a diversity of materials, but also a diversity of meanings and memories (Osterhoudt 2012). Turning towards their fields, individuals are moved to remember moments of their personal past. People gather under the shade of large trees in their fields for ancestral ceremonies; they commemorate the birth of a child by planting fruit trees; they remember departed family members by the trees that they planted throughout the course of their life. And, as I discuss below, interwoven among such personal memories are those that recall the larger trajectories of history, including the traumatic political eras of forced labor, colonialism and war.

\section{Forced labor: rosewood}

Both the Imperial and French colonial periods of Malagasy history included the widespread use of forced labor, called fanompoana. ${ }^{7}$ Under such systems, the French and the elite members of the ruling Merina group of the highlands had the authority to conscript Malagasy residents of other ethnicities, or people of the non-royal classes, for labor on public work projects such as irrigated rice production, infrastructure construction, or plantation agriculture (Campbell 2012; Larson 2000). ${ }^{8}$ This work took men and women away from their communities and often led to sickness and death. Historians of Madagascar attribute the eventual downfall of the Merina Kingdom and French colonialism largely to their overreliance on fanompoana, as these policies proved extremely unpopular with the Malagasy populace, and also removed men and women from their fields at important points during the agricultural calendar (Larson 2000; Campbell 2005). ${ }^{9}$

While I found people reluctant to broach the subject of forced labor directly, they would occasionally refer to the subject indirectly while talking about the materials found in their local landscapes. My friend explaining the connection between growing tobacco and the forced labor policies of the French provides one example of this relationship. Another way in which people raised past memories of brutal forced labor regimes was through referencing the present situation regarding the harvest of rosewood trees (Dalbergia spp.) in the Mananara region. While I was conducting my fieldwork, Mananara was embroiled in an international controversy regarding the export of rosewood from the forests of the Northeast (Bearak 2010). The presiding Malagasy president at the time, Andry Rojoelina, had seized power by a coup d'état and most of the international community failed to recognize his government as legitimate, cutting off aid as a result. In response, Rojoelina lifted the ban on exporting rosewood from Madagascar in order to raise revenue for his administration (Barett et al. 2010; Schuurman and Lowry 2009). Environmental groups opposed this measure

\footnotetext{
${ }^{5}$ Landholdings are usually arranged in scattered parcels of between one-quarter and two hectares in size, including lowland areas suitable for paddy rice cultivation and upland areas used for swidden rice cultivation and agroforestry production. Parents generally bequeath their land equally among their children, regardless of gender or birth order.

${ }^{6}$ The diversity of these agroforestry production systems is quite notable. A pilot study I conducted inventorying a sample from the fields of seven vanilla farmers in Imorona, for example, recorded 97 tree species, approximately one-third of which were native or endemic to the region (Osterhoudt forthcoming).

${ }^{7}$ The Imperial period of Madagascar is generally considered to stretch from about 1750 until the turn of the twentieth century. During this time, the Merina royal elite of the Central Highlands (also referred to as the Hova) attempted to extend their rule across the island (Campbell 2005). The French colonial period of Madagascar spanned the period from 1898 until 1960.

${ }^{8}$ On occasion members of the London Missionary Society obtained permission from the Malagasy royal government to use forced labor (Campbell 2012).

${ }^{9}$ The Merina group of the highlands did not represent a politically monolithic group, as the elite royal lineages exercised considerable power over the "common" and the slave classes of the highlands (Campbell 2012; Graeber 2007).
} 
vocally, as it left the country's protected areas vulnerable to large-scale logging operations (Barett et al. 2010; Innes 2010).

Though the rosewood controversy drew heated international debate, local Mananara farmers for the most part said little on the subject, not wanting to call attention to themselves in the midst of the battle between powerful - and oftentimes violent - forces. Smallholder farmers stood to gain little from the rosewood trade; the most they could hope for was to earn five dollars a day in return for the hard work of dragging heavy rosewood logs from the forest to town (see also Schuurman and Lowry 2009). Most residents opted to work their rice fields instead.

If people did comment on the rosewood trade to me, it was to mention that rosewood was a tree with a hard (mafy) history. ${ }^{10}$ Intrigued by this sentiment, I asked a local Mananara historian what this phrase could mean. He told me that throughout the Imperial Merina rule of Madagascar, the royal family sent emissaries to Mananara Nord to govern the area. These officials instituted violent policies, including forcibly conscripting men into fanompoana labor to move large hardwood logs from the Northeastern forests down the coast to the port city of Foulpointe. ${ }^{11}$ These forced labor marches, he told me, were particularly brutal:

Before, [the Merina] would make Betsimisaraka work so hard, dragging trees down the coast. They would start up North in Maroansetra, in the big forests there, and take rosewood logs and then long lines of Betsimisaraka people had to drag the logs all the way down the coast... The Merina used these logs to defend their battlements - they would roll the logs down the hill, against the British and the French when they tried to invade the ports. It was very horrible for the people who had to do this work. There was not enough for people to eat. They had to work all day and all night. Many people died. ${ }^{12}$

Thus, in talking about rosewood logging in the present, individuals in the Mananara region indirectly reflect on the previous forced labor policies of the colonial French and the Merina elite. Seeing these trees once again extracted from their nearby forests, people are reminded of the forms of violence that occur when powerful political and economic entities desire the materials within the local landscapes. By marking rosewood trees as trees with a 'hard history' they become coded as commodities of exploitation - as commodities of loss - of commodities that condense the hard histories born out of struggles for power.

\section{Colonialism: vanilla}

When you meet a farmer in Imorona, they will often make it a point to tell you that they are a vanilla farmer. Indeed, during the weekly English class I taught for a brief spell while a Peace Corps volunteer, the first phrase that everyone asked to learn was: Hello. I am a vanilla farmer. Farming vanilla fundamentally connects to individual identity for people in the region and being a skilled vanilla farmer is a point of pride. Suggesting to people in Imorona that the vanilla orchid vine originally came from Central America is met with skepticism. "Maybe before vanilla was from somewhere else", one farmer told me. "But now, vanilla is Malagasy." 13

\footnotetext{
${ }^{10}$ This phrase reflects the Malagasy penchant for puns and metaphors, as the rosewood tree is a hardwood species and also reflects the hard histories of exploitation. For an in-depth discussion of how Malagasy employ metaphors to discuss times of hardship, see Huff (2014).

${ }^{11}$ Also known by the Malagasy name Mahavelona.

${ }^{12}$ In his study of Imperial Madagascar, Campbell quotes an eye-witness account of workers forced to drag logs in such a manner: "The obtaining of timber was the most laborious work connected with the building [fanompoana]... [I] never saw them either dragging or carrying their timber without great commiseration, as I noticed some of them lame, footsore, and often stretched on the roadside quite exhausted... To the large trees the people attach ropes, or strongly twisted creepers, to both ends, and proceed in one or two rows, pulling with all of their might, and singing or shouting as they pull. I have sometimes seen more than one hundred men dragging a single tree past my house (2005: 129)."

${ }^{13}$ From the perspective of the world market this certainly seems true, as approximately $70 \%$ of the world's vanilla is grown in Madagascar. The vanilla cultivated in Madagascar and nearby islands is known as the Bourbon variety (Vanilla
} 
This profound connection between cultivating vanilla and personal and national identity becomes especially interesting when situated against the backdrop of colonial agricultural politics of the region (cf. Pandian 2009). Madagascar was under French colonial rule from 1898 until 1960 - a period that represents a particularly violent chapter of African colonial history, with an estimated 100,000 Malagasy deaths attributed to colonial actions (Cole 2001; Sodikoff 2004). As part of their politics of rule, the French sought to exercise strict control over the island's agricultural and trade policies, dictating which regions of Madagascar were allowed to cultivate which crops, and requiring Malagasy exports to first go through French ports before then being re-exported to other countries.

Under such colonial agrarian maps, the Mananara region was designated as the place reserved for the cultivation of clove trees and coffee bushes (Osterhoudt forthcoming). ${ }^{14}$ The cultivation of vanilla, on the other hand, was primarily allotted to the Antalaha region of Northeastern Madagascar to the north of Mananara (Campbell 2005; Larson 2000) ${ }^{15}$ A highly valuable crop, French colonial officials wanted to keep vanilla under close watch, and conscripted Malagasy workers from the South of the island to work on the large vanilla plantations owned and operated by French nationals (Middleton 1999). Smallholder farmers in the Imorona and Mananara region, on the other hand, were forbidden to cultivate vanilla within their agroforestry fields, despite the fact that such ecologies offered ideal growing conditions for the vanilla orchid. One government agricultural extension agent I spoke with remembered that the French permitted only a few prominent Mananara farmers to grow a small quantity of green vanilla beans each year, and they could only sell these beans to approved traders, at a price far below what vanilla prices were in Antalaha. The French justified this tight regulation in part by arguing that smallholder farmers did not have the skills to cultivate high quality vanilla, and therefore would harm the overall reputation of the Madagascar vanilla market. ${ }^{16}$

Ironically, it was another policy imposed by the French colonial government that directly undermined this agricultural vision for the Mananara region: that of requiring all male Malagasy residents to pay an annual 'head tax' to the French government. Elder members of Imorona remembered the challenge of earning cash to pay the tax, and many of them resorted to undertaking the long walk North to work for a few months on the vanilla plantations in order to earn wages to pay their taxes. People remembered how working on plantations both taught them how to cultivate vanilla, and also intrigued them as to the value that vanilla commanded as a market crop. One elder from Imorona, whose children are today among the most successful vanilla farmers in Imorona, remembers:

When I was born in Imorona [in 1934], there was already a little bit of vanilla in town, but not too much... The years after I was married I would walked north for many days, up the beach, past big forests, to work for a few months on vanilla plantations. This way, we learned here about vanilla. When people walked back home to Imorona, maybe they borrowed a few vanilla vines to take back to the village. This is how we began to farm vanilla in Imorona. ${ }^{17}$

As Mananara farmers 'borrowed' the vanilla vines from plantations to bring back with them to their fields, the vanilla harvest of the Mananara region began to increase. In response, the French escalated their efforts against smallholder vanilla farmers in the region. Colonial agricultural agents compiled reports

planifolia) and is distinct from the Mexican variety (Vanilla pompona). In general, the Bourbon vanilla beans of Madagascar are considered to be the 'gold standard' of the international vanilla industry (Odoux 2003).

${ }^{14}$ Indeed, both of these crops flourish in Mananara to this day within smallholder agroforestry fields.

${ }^{15}$ During the early nineteenth century, The French first attempted to cultivate vanilla on the uninhabited Mascarene Islands in the Indian Ocean, reasoning that it would be easier to establish plantation economies where there were no native populations to contend with (Campbell 1981). These plantations did not succeed, however, partly because of the difficulty and expense of adequately provisioning the slave and trader populations with enough rice and meat to survive (Campbell 2005). Faced with the failure of this plan, the French then moved their vanilla plantations to Madagascar.

${ }^{16}$ Archival record, Archives nationales d'outre-mer, Aix-en-Provence, France. Standardisation 1929/1932. Record FR ANOM 110COL896/2630.

${ }^{17}$ This dynamic of vanilla 'escaping' plantations to be cultivated in the fields of small-scale growers is paralleled in the case of rubber production in Borneo (Dove 2011). 
advocating burning the fields of smallholder Malagasy farmers who cultivated vanilla without permission. ${ }^{18}$ One Mananara historian remembered the lengths that the colonial agricultural service would go to enforce their monopoly over vanilla cultivation:

The French were strict - mafy - about keeping vanilla out of the villages here. Once officials came to Mananara and confiscated vanilla beans from farmers. They cut up the beans and threw them on the beach and drove over them with a tractor. They threw the vanilla into the ocean and told everyone to stop farming it. But many people did anyway.

This statement - that despite the violent efforts of the French, Malagasy farmers continued to cultivate vanilla - gives a new dimension to the seemingly straightforward declaration of men and women in Imorona: Hello. I am a vanilla farmer. Seen within the larger political context of vanilla's fraught colonial history, proclaiming oneself to be a vanilla farmer in Imorona connects to a long legacy of pride and defiance. Even as colonial officials destroyed their vanilla harvests and threatened to burn their fields, the farmers of Imorona continued to tend to their vines, pollinate flowers, and teach their children the sophisticated art of vanilla cultivation. Upon finally gaining independence from the French, one of the first acts of the new Malagasy president, Philibert Tsiranana, was to open vanilla cultivation up to the farmers of Mananara, while also providing for greater equity and transparency of the vanilla trade (Cadot et al. 2006). ${ }^{19}$ Knowing such political and personal histories, the vanilla vines growing within Mananara landscapes today take on a richer texture - one woven with memories of hope, of resistance, and of resilience.

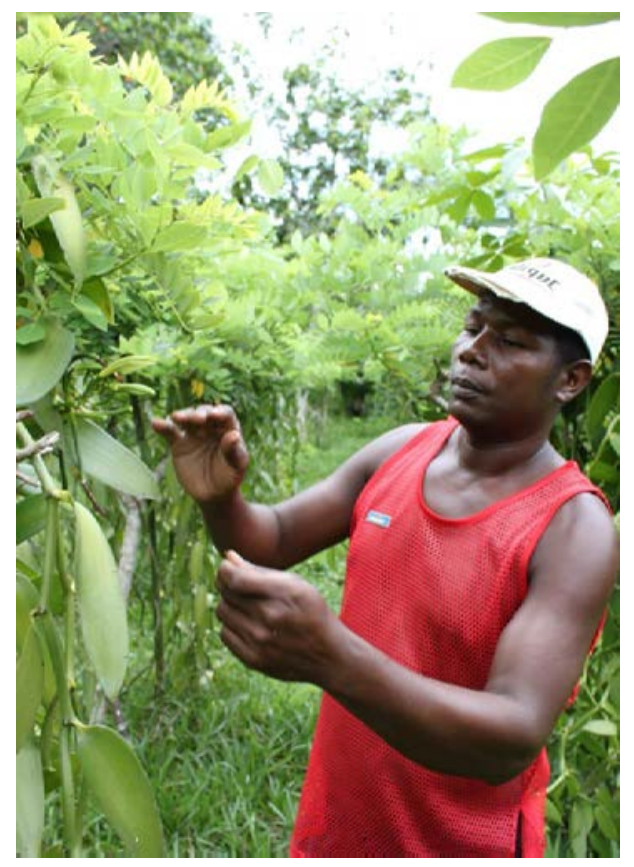

Figure 2: Farmer tending to his vanilla vines in the Mananara Nord region of Madagascar. Source: Author.

\footnotetext{
${ }^{18}$ Archival record, Archives nationales d'outre-mer, Aix-en-Provence, France. Standardisation 1929/1932. Record FR ANOM 110COL896/2630.

${ }^{19}$ Despite such efforts at transparency regulation, the Madagascar vanilla industry remains highly secretive and tightly controlled by a few interests often accused of corruption and collusion. As one industry analyst notes, "the main feature of the international vanilla market is its total opacity" (Odoux 2003).
} 


\section{War and crisis: cloves}

Another crop to occupy a key role in the historical memory of Imorona is the clove tree (Syzygium aromaticum). As mentioned above, the French colonial administration in Madagascar designated the Mananara region to be a production center for cloves. Oral history accounts state that clove trees arrived to Mananara around 1916, and soon spread to the surrounding villages. Today, the Mananara region is a significant global producer of cloves, with an annual harvest of approximately 20,000 tons in an average year. ${ }^{20}$ This production comes from smallholder farmers who own their agricultural land - there are no clove plantations in the region.

The stories people in Imorona tell about clove trees are often connected with memories of political conflict and war - a relationship that I first became aware of in a somewhat unexpected way, as I helped farmers establish a small clove tree nursery in the village. ${ }^{21}$ Towards this effort, local children would scour the ground looking for clove seeds, gathering up the fleshy maroon fruits that had fallen to the ground. They brought these fruits back to my yard, where we collected them in a large bucket. As we worked, people stopped by to see what we were doing. One such visitor was an older woman, who squeezed a clove fruit between her fingers. The pulp oozed rich red liquid onto her hands. Looking down, she told me that back in the time of World War II (krisy i'velany or "the war abroad") people in Imorona used the dye from crushed clove seeds to write with, as pens were not available in local stores.

As my time in Imorona continued, I heard this story recounted many different times. Although it was sometimes unclear if people were referring to World War I or World War II in their accounts, the connection between "foreign" wars and writing with cloves remained consistent. One tangalamena I spoke with, for example, elaborated on how people used crushed clove seeds for ink during the early 1940s - the years of WWII: ${ }^{22}$

During this time [the early 1940s], we students did not have pens and paper. We made our own. Our pencils at that time were made from chicken feet, and we used crushed clove seeds for ink. We had to go and collect banana leaves - green banana leaves for our paper. With these things we did our homework. But it was difficult using banana leaves as paper - we had to know all our lessons in only one day because the next day-- all our writing would be gone!

At first, this particular anecdote seemed to provide an interesting bit of local color, but did not seem especially important from a historical perspective. Yet, the fact that so many different people across generations recounted this story suggests it holds particular salience among members of the Imorona community. Indeed, the anecdote about people writing with cloves during times of war was one of the only things that people did tell me about such periods of time, despite my consistent prodding for more information. ${ }^{23}$ The prominence of this story led me to ask: what is it about this anecdote that gives it such sway over the collective memory of Imorona?

Upon analyzing the story further, certain interesting points emerge. First, the fact that clove fruits were abundant enough in the community to provide students with enough 'ink' for school points to something unusual within the community. Cloves are harvested at the flower bud stage; these buds are then dried and sold. For a clove tree to develop fruits, it means that the flower buds were not harvested, but instead were allowed to develop into flowers and then into fruits. During a normal clove season, there may be some clove

\footnotetext{
${ }^{20}$ Source: FAO Statistics from www.factfish.com. In Madagascar, cloves generally have a three-year harvest cycle, with the third year being a period of 'mast' flowering followed by a year of low production.

${ }^{21}$ In her work with matsutake mushroom pickers, Tsing notes the connection people often make between picking mushrooms and memories of war (Tsing 2015).

22 The tangalamena are the representatives for family lineages who are charged with caretaking the ancestral burial grounds and being the spokesperson for ceremonies and festivals. The position of tangalamena is usually passed down via the male line of the lineage's first tangalamena, though in rare cases a woman can be a tangalamena if there are no suitable male candidates.

${ }^{23}$ People in Imorona also remember the periods of World War I and World War II by remarking on if they had family members who were conscripted to fight. The French conscripted a significant number people from their African colonies, including the Malagasy, to fight in war efforts, including World Wars I and II (Headrick 1978, Rice 2000).
} 
buds that are missed during harvest, and thus a few clove fruits available, but this is not the norm. For my clove nursery project, for example, we found it quite difficult to even find one bucket full of ripe clove seeds.

Thus, the fact clove fruits were readily available during times of conflict suggests that the clove harvests were not occurring as usual. This suggests a lack of trade in cloves - an absence of buying and selling in the village. Related to the abundance of clove seeds lying on the ground was the lack of pens available in stores: another marker of trade stagnation. Thus, not only were cloves not moving out of the village, but trade goods were not coming into the community either. This slowing down of trade, in turn, represents a disturbing departure from regional norms. ${ }^{24}$ Indeed, when speaking with people about what they feel most disrupts the "good life", many people said it is when circulation of trade goods slows down - when things stop moving. Even in times of hardship, people told me, as long as trade is happening, life can overall proceed as normal, and with at least a modicum of hope.

Secondly, the fact that this historical anecdote emphasizes how materials from the forest were used for matters of learning illustrates another up-ending of the regular order of things. Malagasy culture has a long history of connecting written knowledge with specific forms of cultural and political power (Bloch 1998; Rich 2008). The Malagasy language was first translated into writing in the fifteenth century, using Arabic script known as sorabe.$^{25}$ Knowledge of this script was largely confined to royal advisors, who were thought to be able to access the spiritual power of hasina through writing (Larson 2000). Today, being literate in Madagascar continues to convey elements of both "virtue and power" (Bloch 1998:136). These forms of power stand distinct from the everyday, mundane realms including the manual labor of agriculture. Thus, by using cloves to write with, the divisions between small-scale farming activities and academic learning activities became blurred. Furthermore, the fact that the writing on banana leaves would "vanish within a day" destabilizes the Malagasy association of written knowledge as representing a lasting, permanent record (Larson 2000; Rich 2008).

Overall, by remembering how people in Imorona were forced to write with the dye from crushed clove seeds during times of conflict, people are able to discuss the hardships and uncertainties of war without directly talking about the war itself. Instead, they talk about their changing relationship to the clove tree, using this relationship as a reflection of the changing economic, political, and cultural landscapes of the time. By pointing out how war is a time of writing with seeds, people are commenting more broadly on the unstable turns of history.

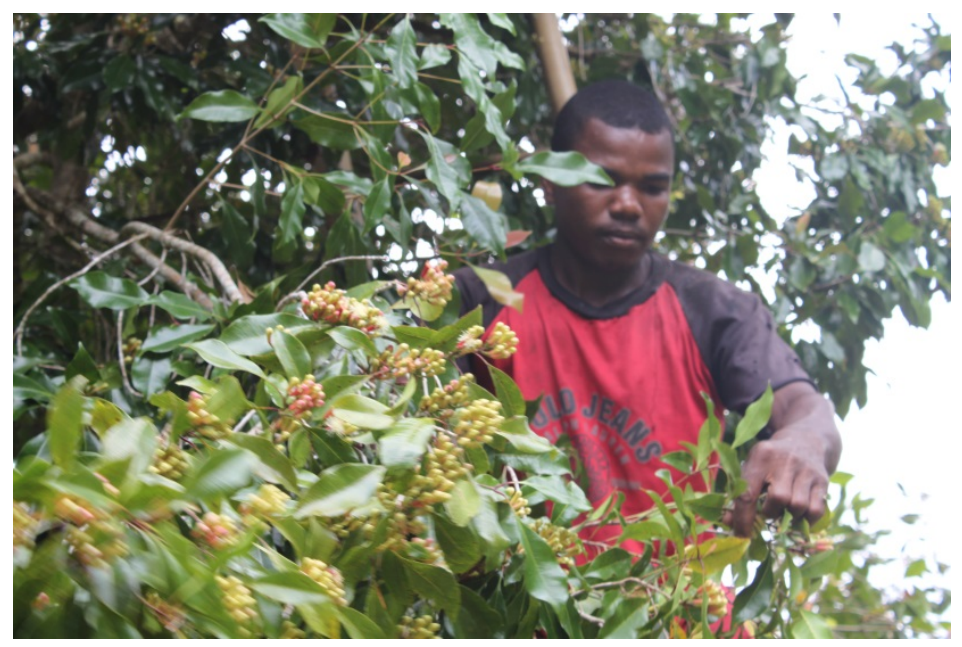

Figure 3: Harvesting clove buds in Imorona, Madagascar. Source: Author.

\footnotetext{
${ }^{24}$ Economic data taken from Madagascar as a whole show that exports from Madagascar significantly declined during wartime years (Campbell 2012).

${ }^{25}$ Through the work of the London Missionary Society, the Malagasy alphabet was translated from Arabic into the Roman alphabet during the early 1800s (Cousins 1894).
} 


\section{Landscapes of power and resistance}

As illustrated by the stories of rosewood, vanilla, and cloves, Malagasy farmers connect the commodities cultivated in their fields with broader trajectories of political and economic histories. At first glance, such memories seem to primarily reflect the ways smallholder farmers suffered under the hegemonic regimes of history. However, just as local landscapes carry memories of violence, subjugation and loss, they also present people with narratives of resistance and triumph. For example, the story of the brutal forced labor marches down the coast can be considered in conjunction with another landscape memory - one related to a reef-protected stretch of Imorona's beach (Figure 4). As I walked with a friend along this beach one afternoon, she pointed to some large stones jutting out of the blue water:

...on [forced labor] marches [down the coast], people walked along the ocean and had to cross many rivers. The Betsimisaraka, they knew the places where the water was shallow [like this reef in Imorona], and at these places someone may try to escape. He would lie in the water and pretend to be a rock, like these other rocks and the hova [merina] would not notice - they would think this person was a rock.

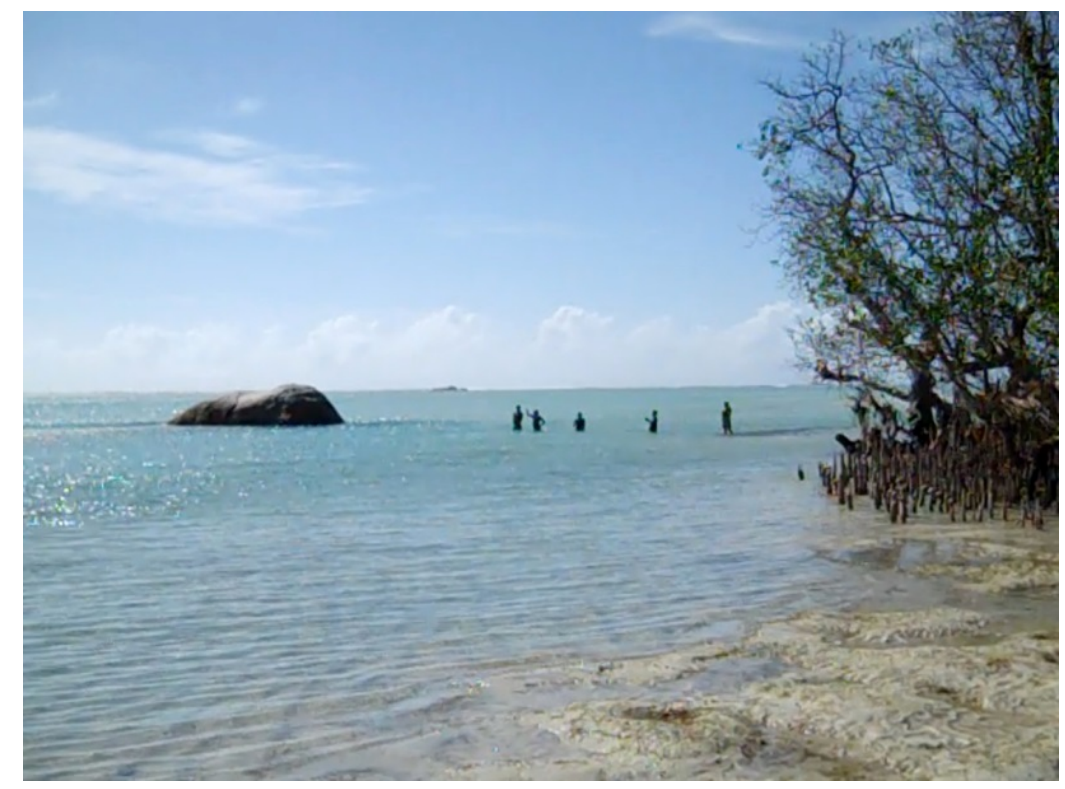

Figure 4: People fishing near a rock within the reef-protected mangrove beach of Imorona, Madagascar. Source: Author.

Listening to landscape histories of Imorona, one learns of an array of tactics that farmers have used over time to contest groups with greater political and economic power. These tactics range from forms of direct political defiance, to more subtle cultural maneuvers ( $\mathrm{Li} \mathrm{1999;} \mathrm{Scott} \mathrm{2008).} \mathrm{While} \mathrm{the} \mathrm{story} \mathrm{of} \mathrm{escaping}$ the forced labor marches illustrates an obvious strategy of defiance, the community's collective memory also contains many examples of more subtle ways that farmers responded to those who sought to control them. Indeed, each of the commodity memories discussed above represents a degree of proactive maneuvering by local farmers in the face of extra-local power structures. Exhausted farmers rolled up banana leaves to fool colonial overseers into giving them a break from their labor. Imorona residents tucked away vanilla vines from colonial plantations as they made their way back home to the village. Faced with the collapse of the clove trade during World War II, people gathered the clove fruits scattered on the ground, crushing them in their fingers to create tools for students to continue with their learning. 
One common thread uniting these strategies is that locals used their keen knowledge of their ecologies to resist outsiders imposing violent forms of rule. Farmers knew where the ocean was shallow and how to 'hide' vanilla vines within their agroforestry fields. They knew how to creatively use the agricultural materials cultivated in fields and forests to their best advantage. They mobilized their local knowledge to mitigate the power of extra-local forces, as the landscape itself emerged as a key ally of history.

The stories of power and resistance told by Imorona farmers denote not only memories of the past, but resources for the present. Farmers in the region currently face many of the same challenges they have faced for centuries, most notably how to capitalize on the powerful economic and political entities that come to their communities in search of trade while at the same time holding them at arms' length (Dove 2011). By remembering stories of how their ancestors navigated volatile trade relationships, or cultivated new market commodities, or opposed oppressive governments, people share strategies of resiliency and resistance (Huff 2014). Such memories simultaneously serve as tales of warning and of inspiration.

In this way, a 'political ecology memory' framework historicizes what Rajan and Duncan have termed an "ecology of hope" - a concept they describe as the localized "middle" space that examines change and agency through recognizing "humanity and nature in action" (2013:71). In Imorona, the rocks on the shore, the clove buds on a tree, the vanilla vines in an agroforestry field all provide people with concrete material ecologies within which to locate and articulate their own personal and political histories, as they cultivate shared stories of hope and resistance.

\section{Discussion: towards a political ecology of memory}

In talking of the materials found in their local ecologies, Malagasy farmers reflect upon the painful political eras of their collective past - memories that otherwise remain largely silenced within Malagasy cultural norms. Working in their fields, a tobacco plant recalls brutal forced labor policies; vanilla vines the colonial gaze of power; clove trees the hardships wrought by war. Examining how memories of extra-local political histories become embodied and articulated through personal stories of local ecologies is a "political ecology of memory" approach to history.

This framework incorporates the strengths of political ecology and of environmental anthropology. From a political ecology perspective, examining the histories connected to local ecologies draws from the seminal work of Eric Wolf, who foregrounds the alternative perspectives of groups often overlooked in hegemonic accounts of global histories (1982). In analyzing how local communities shaped - and were shaped by -- extra-local relationships Wolf and other early political ecologists encouraged scholars to draw connections across historical and spatial scales (e.g. Blaikie 1985; Mintz 1985; Thompson et al. 1986). Later research in political ecology focused on the discursive and epistemological dimensions of power, especially the role of knowledge production in creating and perpetuating regimes of control over natural resources (e.g. Brosius 1999; Dove 1983; Fairhead and Leach 1996). More recently, political ecology has addressed the qualitative, individualized reactions to global networks of environmental power, examining how people move through localized spaces, and how large-scale power dynamics are embodied through cultural anxieties and identities (e.g. Hulme 2011; Robbins and Moore 2013; Zanotti 2014).

In examining the connections between global politics, international trade histories, and the agrarian landscapes of Madagascar, I follow within this analytical tradition. At the same time, by collecting historical narratives on a person-by-person and tree-by-tree basis, I bring community histories to the level of the individual, asking: How do individuals articulate and embody the collective memories of extra-local relationships of politics and trade? This ethnographic methodology notes the ways global histories are remembered in practice: in this case, through the mundane tasks of agriculture. Working in their fields, the quotidian acts of harvesting cloves, pollinating a vanilla flower, or walking back home along a rocky stretch of beach may cause one to recall memories of the past. In such ways, the slow and steady work of cultivating land is also the slow and steady work of cultivating history.

By taking an up-close approach to the meanings people bestow on their landscapes, this research draws from the early anthropological work of Victor Turner. In his Forest of symbols, Turner investigates ways the Ndembu of Zambia turn to the realms of ritual to bestow their environment with shared meanings (1967). More recently, referencing Turner's work, the anthropologist Lilith Mahmud similarly examines ways that 
cultural groups superimpose symbols onto local landscapes - in her case, she turns to Freemason "secret" societies in Florence, Italy (2012). She argues that the initiation rituals of the Freemasons cause members of the group to code the urban Florence landscape with shared meanings. A Freemason will thus gaze upon the city with a different consciousness compared to someone who did not go through similar initiations. In the process, she writes, memories become "hidden in plain sight" across landscapes (Mahmud 2012). In the same way, farmers of Imorona code their local landscapes with the shared symbols of historical memory. However, people in Imorona do not only instill landscapes with meanings through the exceptional realms of ritual, as explored by Turner and Mahmud, but also through their routine, mundane interactions with landscapes.

Throughout the Mananara region, over time these shared landscape symbols foster insiders and outsiders to local history. Insiders in Imorona understand these layered meanings of history. They know how to infuse seemingly simple acts of harvesting cloves or pollinating vanilla with a larger sense of memory and history. Outsiders, on the other hand, may easily miss the symbols around them. Collectively, locating ideas of the past in the landscapes of the present allows painful histories to remain largely unspoken, yet not forgotten (Cole 2001).

Overall, adopting a political ecology of memory framework in Madagascar illustrates how the commodities people cultivate on their local landscapes mediate between historical trajectories of extra-local political and economic forces 'writ large' and the intimate spheres of memory, identity and personhood 'writ small.' Indeed, commodity crops are especially productive sites for the articulation and re-articulation of relationships across scales, being materials that bridge local farmers with the messy entanglements of extralocal economic, political, and cultural systems (Tsing 2014). By listening to the stories Imorona smallholder farmers tell about agriculture and trade -- stories that emerge as stories of politics, of power, of violence, and of loss -- we hear how people render global histories personal. In such ways, a political ecology approach to memory simultaneously bridges us outwards towards others, and inwards towards self.

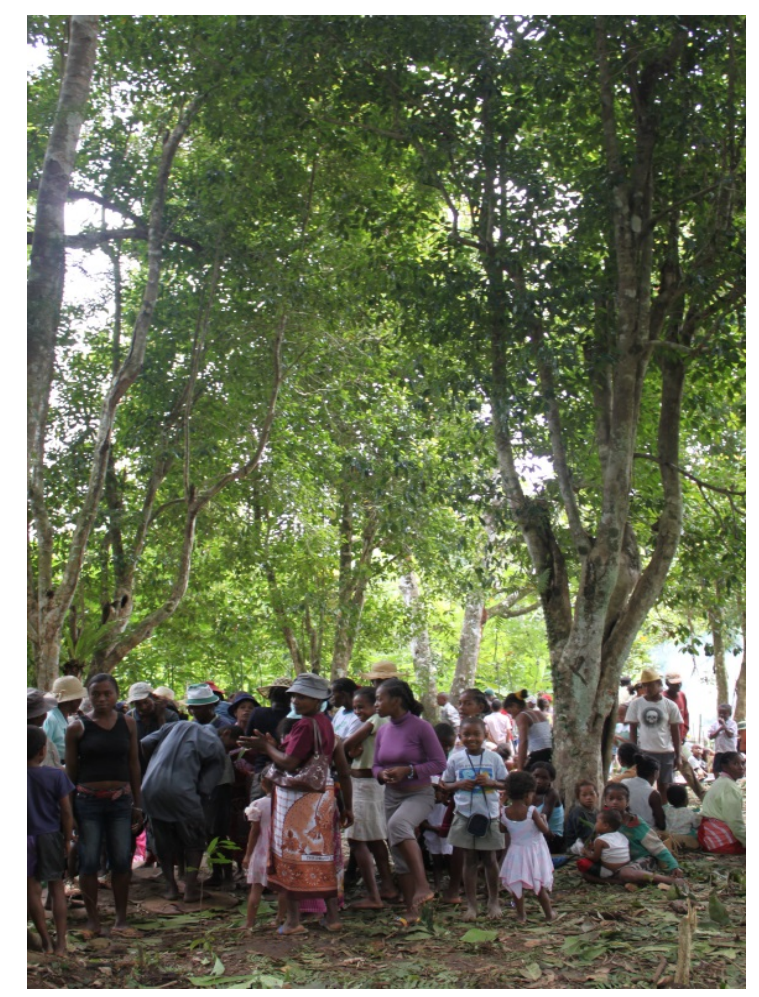

Figure 5: Gathering in an agroforestry field for an ancestral ceremony in the Mananara region, Madagascar. Source: Author. 


\section{References}

Barrett, M.A., J.L.Brown, M.K. Morikawa, J.N. Labat, J.N. and A.D. Yoder. 2010. CITES designation for endangered rosewood in Madagascar. Science 328(5982): 1109-1110.

Basso, K.H. 1996. Wisdom sits in places: landscape and language among the Western Apache. Tucson: University of New Mexico Press.

Bearak, B. 2010. Tottering rule in Madagascar can't save falling rosewoods. New York Times. May 24. (online with different title)

Biersack, A. 2006. Reimagining political ecology: culture/power/history/nature. In Biersack, A. and J.B. Greenberg (eds.) Reimagining political ecology. Durham: Duke University Press. Pp 3-42.

Blaikie, P.M. 1985. The political economy of soil erosion in developing countries. London: Longman.

Bloch, M.1977. The past and the present in the present. Man 12: 278-292.

Bloch, M. 1985. Almost eating the ancestors. Man 20(4): 631-646.

Bloch, M. 1998. How we think they think: anthropological approaches to cognition, memory, and literacy. Oxford: Westview Press.

Brosius, J.P. 1999. Green dots, pink hearts: displacing politics from the Malaysian rain forest. American Anthropologist 101(1): 36-57.

Bryant, R.L. 1998. Power, knowledge and political ecology in the third world: a review. Progress in Physical Geography 22(1): 79-94.

Cadot, O., J. De Melo, and L. Dutoit. 2006. The elimination of Madagascar's Vanilla Marketing Board, ten years on. Policy Working Papers, World Bank Group. http://elibrary.worldbank.org/doi/abs/10.1596/1813-9450-3979

Campbell, G. 1981. Madagascar and the slave trade, 1810-1895. The Journal of African History 22(2): 203227.

Campbell, G. 2005. An economic history of Imperial Madagascar, 1750-1895: the rise and fall of an island empire. Cambridge: Cambridge University Press.

Campbell, G. 2012. David Griffiths and the missionary "History of Madagascar." Leiden: Brill.

Cole, J. 2001. Forget colonialism? Sacrifice and the art of memory in Madagascar. Berkeley and Los Angeles: University of California Press.

Cousins, W.E. 1894. A concise introduction to the study of the Malagasy language as spoken in Imerina. Antananarivo Madagascar.

Donque, G. 1972. The climatology of Madagascar. Netherlands: Springer.

Dove, M.R. 1983. Theories of swidden agriculture, and the political economy of ignorance. Agroforestry Systems 1(2): 85-99.

Dove, M.R. 1999. The agronomy of memory and the memory of agronomy: ritual conservation of archaic cultigens in contemporary farming systems. In Nazarea, V.D. (ed.) Ethnoecology: situated knowledge / located lives. Tucson: University of Arizona Press. Pp. 45-70.

Dove, M.R. 2011. The banana tree at the gate: a history of marginal peoples and global markets in Borneo. New Haven: Yale University Press.

Ellis, S. 2007. Tom and Toakafo: the Betsimisaraka kingdom and state formation in Madagascar, 17151750. The Journal of African History 48(03): 439-455.

Fairhead, J. and M. Leach. 1996. Misreading the African landscape: society and ecology in a forest-savanna mosaic. Cambridge: Cambridge University Press.

Giles-Vernick, T. 2001. Lives, histories, and sites of recollection. In White, L., S. Miescher and D.W. Cohen (eds.). African words, African voices: critical practices in oral history. Bloomington: Indiana University Press. Pp. 194-213.

Graeber, D. 2007. Lost people: magic and the legacy of slavery in Madagascar. Bloomington: Indiana University Press. 
Headrick, R. 1978. African soldiers in World War II. Armed Forces and Society 4(3): 501-526.

Huff, A. 2014. Weathering the 'long wounded year': livelihoods, nutrition and changing political ecologies in the Mikea Forest Region, Madagascar. Journal of Political Ecology 21: 83-107.

Hulme, M. 2011. Reducing the future to climate: a story of climate determinism and reductionism. Osiris 26(1): 245-266.

Innes, J.L. 2010. Madagascar rosewood, illegal logging and the tropical timber trade. Madagascar Conservation and Development 5(1): 6-10.

Jackson, J.B. 1984. Discovering the vernacular landscape. New Haven: Yale University Press.

Kottak, C.P. 1980. The past in the present: history, ecology, and cultural variation in highland Madagascar. Ann Arbor: University of Michigan Press.

Kull, C.A. 2002. Madagascar aflame: landscape burning as peasant protest, resistance, or a resource management tool? Political Geography 21(7): 927-953.

Lambek, M. 2002. The weight of the past: living with history in Mahajanga, Madagascar. New York: Palgrave Macmillan.

Larson, P.M. 2000. History and memory in the age of enslavement: becoming Merina in highland Madagascar, 1770-1822. Oxford: James Currey.

Li, T.M. 1999. Compromising power: development, culture, and rule in Indonesia. Cultural Anthropology 14(3): 295-322.

Li, T.M. 2014. Land's end: capitalist relations on an indigenous frontier. Durham: Duke University Press.

Mahmud, L. 2012. "The world is a forest of symbols": Italian freemasonry and the practice of discretion. American Ethnologist 39(2): 425-438.

Meitzner Yoder, L. 2011. Political ecologies of wood and wax: sandalwood and beeswax as symbols and shapers of customary authority in the Oecusse enclave, Timor. Journal of Political Ecology 18: 11-24.

Middleton, K. 1999. 'Who killed Malagasy cactus'? Science, environment and colonialism in southern Madagascar (1924-1930). Journal of Southern African Studies 25(2): 215-248.

Mintz, S.W. 1985. Sweetness and power. New York: Viking Press.

Nazarea, V.D. 2006. Cultural memory and biodiversity. Tucson: University of Arizona Press.

Odoux, E. 2003. The international vanilla market. Fruitrop 98(January): 4-7. http://passionfruit.cirad.fr/index.php/download/(id)/2259/(langue)/eng/(type)/article

Olson, S.H. 1984. The robe of the ancestors: forests in the history of Madagascar. Journal of Forest History 28: $174-186$.

Osterhoudt, S.R. 2012. Sense and sensibilities: negotiating meanings within agriculture in northeastern Madagascar. Ethnology 49(4): 283-301.

Osterhoudt, S.R. forthcoming. Vanilla landscapes: meaning, memory and the cultivation of place in Madagascar. New York: New York Botanical Garden Press.

Pandian, A. 2009. Crooked stalks: cultivating virtue in South India. Durham: Duke University Press.

Peet, R., P. Robbins and M.J. Watts (eds.). 2010. Global political ecology. London and New York: Routledge.

Rajan, S.R. and C.A.M. Duncan. 2013. Ecologies of hope: environment, technology and habitation-case studies from the intervenient middle. Journal of Political Ecology 20: 70-79.

Randrianja, S., and S. Ellis. 2009. Madagascar: a short history. London: Hurst Publishers.

Rich, C.H. (ed.). 2008. The fifohazana: Madagascar's indigenous Christian movement. Amherst, NY: Cambria Press.

Rice, L. 2000. African conscripts/European conflicts: race, memory, and the lessons of war. Cultural Critique 45: 109-149.

Robbins, P. and S.A. Moore. 2013. Ecological anxiety disorder: diagnosing the politics of the Anthropocene. Cultural Geographies 20(1): 3-19. 
Schuurman, D. and P.P. Lowry II. 2009. The Madagascar rosewood massacre. Madagascar Conservation and Development 4(2): 98-102.

Scott, J.C. 2008. Weapons of the weak: everyday forms of peasant resistance. New Haven: Yale University Press.

Sodikoff, G. 2004. Land and languor: ethical imaginations of work and forest in northeast Madagascar. History and Anthropology 15(4): 367-398.

Thompson, M., T. Hatley, and M. Warburton. 1986. Uncertainty on a Himalayan scale: an institutional theory of environmental perception and a strategic framework for the sustainable development of the Himalaya. London: Milton Ash Editions, Ethnographica Publishers. section

Tsing, A.L. 2005. Friction: an ethnography of global connection. Princeton: Princeton University Press.

Tsing, A.L. 2015. The mushroom at the end of the world: on the possibility of life in capitalist ruins. Princeton: Princeton University Press.

Turner, V.W. 1967. The forest of symbols: aspects of Ndembu ritual. Ithaca: Cornell University Press.

Walsh, A. 2005. The obvious aspects of ecological underprivilege in Ankarana, northern Madagascar. American Anthropologist 107(4): 654-665. On Academia

Wolf, E.R. 1982. Europe and the people without history. Berkeley and Los Angeles: University of California Press.

Zanotti, L. 2014. Political ecology of movement: trekking and territoriality among the Kayapó. Journal of Political Ecology 21: 108-126. 